\title{
Preconditions of the Manifestation of Teacher's ICT Competence in the Study Programmes
}

\author{
Brigita Janiunaite, Vitalija Jakstiene, Gintautas Cibulskas \\ Kaunas University of Technology
}

\begin{abstract}
The article addresses the following research question: how does a study programme create premises for the manifestation of teacher's ICT competence? This problem is solved in four parts of the article. In the first part the ICT competence of a university teacher is defined; the second part reveals the coherences of teacher's ICT competences and ICT implementation levels; the third part presents the research methodology. The fourth part reveals the coherences of teacher's ICT competence and the study programme.
\end{abstract}

Keywords: ICT, ICT competence, teacher, study programmes.

\section{Introduction}

Due to the need for life-long learning in the society as well as pursuing for flexibility and effectiveness of university studies, the role of information communication technologies (ICT). Due to new possibilities, ICT application is widely discussed in research literature [5], [6], [2], [18] and others. ICT is also a challenge for a university teacher. Their application enables new education means, methods, changing students' and teachers' relationship; this is reflected in the study programmes [4], [3]. In this context, ICT competence of a university teacher becomes particularly important [9].
Research literature reveals teachers' ICT activities, abilities, viewpoints or their activities and abilities in certain cases [7], [17], [2], [15], [18] and others), substantiates the ICT competence of a university teacher [9], discloses its levels [10]. However, for the effective ICT application it is important that a teacher understands the benefit provided by ICT and is determined to apply ICT in the educational activity. Research literature analyses what is necessary for a teacher to use ICT [19]; however, coherences of the manifestation of teacher's ICT competence and the study programme have not been revealed. If study programmes and study subjects emphasise ICT, teachers must use ICT; thus they need ICT competence. If ICT application is not reflected in the study programme or study subject, ICT application depends on the teacher's competence and especially motivation. Thus the following question emerges: how does a study programme make premises for the manifestation of teacher's ICT competence? This question defines the research problem.

The aim of the article is to disclose the coherences of the manifestation of teachers' ICT competence and the study programmes of different areas.

The methods of research literature analysis and document analysis were applied. 


\section{Teacher's ICT competence and dif- ferent levels of ICT implementation: theoretical background}

The model by Molz et al. [14] was chosen for identification of teacher's ICT competence in the different levels of ICT implementation. Referring to Molz et al. [14], in the zero level teaching/learning takes place in a particular physical space (e.g., in a classroom) with no ICT used. Thus at the first level a teacher needs at least elementary technological literacy (knowledge on main principles of the work with ICT, ability to communicate, to store academic information, etc.), information literacy (the ability to find and use information relevant for studies), socio-cultural literacy (by using ICT showing respect for other people's intellectual property).

At the second ICT implementation level the specific physical space is emphasised; however, ICT enrich the teaching/learning process. During classes, when conveying the study subject content, slides or another visual material are demonstrated, which enables a more thorough presentation of the subject analysed [12]. Hand-outs are given to students by placing them into digital memory or sending them by e-mail (the use of e-mail is not a complicated action, thus it is possible to argue with Molz et al. [14], who attribute it to a higher level).

Thus in the second level the ICT competence of a teacher involves technological literacy (the ability to use and manage ICT); information literacy (the ability to find and use the relevant information), socio-cultural literacy (by using ICT to respect the intellectual property of other people, the observance of privacy and confidentiality), the pedagogical ICT competence (the appropriate choice of ICT means), the managerial ICT competence (in organizing the self-learning with ICT.
In the third ICT implementation level virtual educational spaces, when e-mail, chat, video-conferences and alike are used, are emphasised [14].

Referring to Peters [16], teaching can be transferred into virtual space or students' learning enabled.

The fourth level of ICT implementation is related to learning networks, virtual communities, humanity multimedia library, advanced internet technologies [14].

Thus the higher level of ICT application, the higher ICT competence is necessary for the realisation of the pedagogical system. The elements of the pedagogical system can have relations with ICT and they are reflected in study programmes and study subjects. Thus in analysing study programmes and study subjects, teacher's ICT competence can manifest in them.

\section{The research methodology}

The method of document analysis to collect the data and the method of descriptive content analysis to process the data was applied in order to investigate the problem analysed in this article.

The research was carried out at Kaunas University of Technology. The study programmes in physical and educational sciences with the best evaluation average of the study subjects were selected from each group of the study trends present at the university (natural sciences, mathematics and computer science, social studies, business and administration, education).

The coherences of the manifestation of teacher's ICT competence and study programmes are disclosed by analysing the official written documents (study programmes and the programmes of study subjects). 


\section{The research results}

In the study programme of physics ICT application is emphasised in the programme abstract: a graduate possesses the knowledge of 'experimental research and technology computerisation', is able to 'use modern information technologies and apply them in physical technologies'. Specific ICT can be used for computerisation of experimental research and technologies as well as ICT application in physical technologies. The comprehensive aims of the programme point out subject knowledge on 'fundamentals of computer programming, creation and programming of programmes', 'mathematical packages' as well as the transferable ability 'to use information technologies, such as ... programming'. The subject knowledge on 'basic Microsoft Office packages', transferable skills 'to use information technologies, such as writing of text documents, drawing of tables, graphic processing of information', 'the use of the Internet' are pointed out in the aims of the programme. The practical ability 'to creatively work with computer technique, to use modern information technologies, to apply them in high technologies' does not clearly disclose what ICT they are.

The requirements for degree emphasise the skills 'of the search for information sources and their qualified analysis', ability 'to clearly and correctly present the outcomes of the research and the product created for different audiences in written and oral forms'.

In the programme of physics there are several study subjects, which refer to ICT in their titles ( 2 of them are of informatics area, 1 - of physics). One of them (Study Subject F1) reveals the coherences of the subject to ICT and this is reflected in the title; another study subject (F2) does not have any reference to ICT.

The aim of Study Subject F1 emphasises the knowledge on 'computer controlled experiment' as well as the ability 'to use complicated computerised measurement systems'. The conveyed knowledge and abilities stress that a student has 'to be able to computerise a simple experiment'. The conveyed knowledge and abilities ('to understand principles of personal computer $(P C)$ structure', 'to understand fundamentals of the work with the equipment being programmed', 'to understand the structure of programme controlled experiment workplaces') disclose that students need training to use specialised ICT; thus a teacher familiarizes students with the principles and structure of the work. Thus once again the necessity for subject ICT competence of the study subject teacher is indicated.

The ability 'to properly present results, to perform their statistical analysis according to formulated criteria' can be related to ICT application both in presenting the results and in performing the analysis. ICT are reflected in the study subject content as well. The topics directly refer to ICT application, e.g., 'The computerpart of information-measurement system', 'Modern computerised experiments and measurements', 'Work with the computerised measurement system'. Here ICT are the means to perform specific activity related to the subject of physics. The topics 'Computer structure, information interchange and programming', 'Interfaces, converters: primary, $A D C, D A C$ and others' can analyse theoretical matters without ICT application.

The assignments - individual work, colloquium, defence of the laboratory work, examination - are assessed. Even though details on the individual work are not given, its assessment as well as of the laboratory work makes 10 per cent each of the final grade. The examination and colloquium make the greatest influence upon the grade. It may be noted that practical work in this study subject is not the 
most important and knowledge is assessed mostly.

The discussed ICT application aspects show the second level of ICT competence (a teacher uses ICT directly meeting students).

\section{Conclusions}

1. The manifestation of teacher's ICT competence is conditioned by the pedagogical system reflected in the study programme and the study subjects. The teacher possessing higher ICT competence than is required in the study programme or the study subject may revise the study subject or study programme by initiating changes in the pedagogical system.

2. The manifestations of teacher's ICT competence became evident in analysed study programme. The second-level ICT application was emphasised in the study programmes of physics. In the study subjects of the programme in physics the premises for the manifestation of the second or the third level of the teacher's ICT competence are created. However study programme contain study subjects, which do not possess any premises for ICT competence manifestation.

\section{References}

[1] Afonin, A. (2009). Key WEB 2.0 services in education [Electronic versijon]. Innovation and Creativity in e-Learning, 20th November, 2009, Kaunas, Lithuania: international conference proceedings. Kaunas University of Technology.

[2] Ardizzone, P., and Rivoltella, P.C. (2006). Teachers, Tutors, and Men- tors: New Roles or Professionals? In A. Cartelli (Eds.), Teaching in the Knowledge Society: New Skills and Instruments for Teachers (pp. 100114). Hershey, PA: Information Science Publishing. Retrieved November 10, 2008 from InfoSci-Books database.

[3] Barnett, R., and Coate, K. (2006). Engaging the Curriculum in Higher Education. Bell \&Bain Ltd.

[4] Bowden, J., and Marton, F. (1998). The University of Learning. Beyond quality and competence. London: Routledge.

[5] Brown, D.G. (2002). Proven Strategies for Teaching and Learning. In A.J. Kallenberg, M.J.J.M. van de Ven (Eds). The New Educational Benefits of ICT in Higher Education Proceedings: (pp.9-11). Rotterdam: Erasmus Plus.

[6] Forsblom, N., and Silius, K. (2002). What is the Added Value of Webbased Learning and Teaching? The Case of Tampere University of Technology. In A.J. Kallenberg, M.J.M. van de Ven (Eds). The New Educational Benefits of ICT in Higher Education Proceedings: (pp.18-25). Rotterdam: Erasmus Plus.

[7] Goodyear, P., Salmon, G., Spector, J.M., Steeples, C., and Tickner, S. (2001). Competencies for online teaching: A special report. Educational Technology Research and Development, 49, (1), 65-72. Retrieved January 13, 2009 from SpringerLink database.

[8] Hanke, H., and Neumann, A. (2007). Education Portal Strategy. In M. Khosrow-Pour (Eds.). Managing Worldwide Operations and Communications with Information Technology, (pp. 1577-1580). Hershey, PA: IGI Publishing. 
[9] Jakštienè, V., and Janiūnaitè, B. (2009). Holism of information and communication technology competence of university teachers. Changes in Social and Business Environment: proceedings of the 3rd international conference, November 4-5, 2009, Kaunas University of Technology Panevėžys Institute, Lithuania: selected papers, 146-153 Kaunas, Technologija.

[10] Jakštienè, V., and Janiūnaitè, B. (2010). Universiteto dèstytojo informaciniu ir komunikaciniu technologiju kompetencija skirtinguose IKT panaudojimo lygiuose. Jaunuju mokslininku darbai, 1, (26), priedas [elektroninis išteklius], 281-288. Šiaulių universiteto leidykla.

[11] Jucevičienè, P. (2007). Besimokantis miestas. Monografija. Kaunas: Technologija.

[12] Jucevičienè, P., and Simonaitienè, B. (2008). Tarpdalykinès magistrantūros programa ir jos igyvendinimo modelis, adaptuotas darnaus vystymosi programai. Kauno technologijos universitetas. Kaunas [i.e. Vilnius]: Biznio mašinų kompanija.

[13] Kardelis, K. (2007). Moksliniu tyrimu metodologija ir metodai. Šiauliai: „Lucilijus“.

[14] Molz, M., Eckhardt, A., and Schnotz, W. (2002). Suggestions for Better Integrating ICT enhanced Instructional Approaches into Campus-Based Higher Education. In A.J. Kallenberg, M.J.J.M. van de Ven (Eds). The New Educational Benefits of ICT in Higher Education Proceedings: (pp.45-52) Rotterdam: Erasmus Plus.

[15] Parchoma, G. (2007). Visualizing ICT Change in the Academy. In C. Van Slyke (Eds.). Information Communication Technologies: Concepts, Methodologies, Tools, and Applications. (pp. 3695-3715). Re- trieved November 12, 2008 from InfoSci-Books database.

[16] Peters, O. (2003). Distance Education in Transition: New Trends and Challenges. University of Oldenburg.

[17] Sales, G.C. (2005). Developing Online Faculty Competencies. In C. Howard, J. Boettcher, L. Justice, K. Schenk, P. Rogers, G. Berg (Eds.). Encyclopedia of Distance Learning, Vol. 2 (pp. 547-553). Retrieved November 14, 2008 from InfoSciBooks database.

[18] Schneckenberg, D. (2007). eCompetence Development Measures for Faculty in Higher Education - A Comparative International Investigation (Dr. phil. dissertation, der Universität Duisburg-Essen, 2007).

[19] Stensaker, B., Maassen, P., Borgan, M., Oftebro, M., and Karseth, B. (2007). Use, updating and integration of ICT in higher education: Linking purpose, people and pedagogy. Higher Education, 54, 417433. Retrieved March 20, 2011, from SpringerLINK databse.

[20] Tamošiūnas, P. (2009). E. mokymas 2.0, perspektyvos Lietuvos aukštojo mokslo institucijose [Electronic version]. Innovation and Creativity in e-Learning, 20th November, 2009, Kaunas, Lithuania: international conference proceedings. Kaunas University of Technology.

[21]Zwaneveld, B., and Bastiaens, T. (2008). ICT competences of the teacher: About supporting learning and teaching processes with the use of ICT. Joint Open and Working IFIP Conference ICT and Learning for the Net Generation. Retrieved March 30, 2009 from The IFIP Digital Library web site http://dl.ifip.org/iojs/index.php/ifip/ article/viewFile/1006/10. 